Jurnal Tanah dan Sumberdaya Lahan Vol 8 No 1: 293-300, 2021

e-ISSN:2549-9793, doi: 10.21776/ub.jts1.2021.008.1.32

\title{
LAJU INFILTRASI PADA BERBAGAI NAUNGAN DI KEBUN KOPI RAKYAT SUMBERMANJING WETAN
}

\section{Infiltration Rate on Various Canopy Cover types in Smallholder Coffee Plantation of Sumbermanjing Wetan}

\author{
Adinda Ardana Reswari, Sugeng Prijono* \\ Jurusan Tanah, Fakultas Pertanian, Universitas Brawijaya, Jl. Veteran No. 1, Malang 65145 \\ *Penulis korespondensi: spj-fp@ub.ac.id
}

\begin{abstract}
Climate change in coffee cultivation is very influential and can disrupt the hydrological cycle, so shade planting is required. Planting vegetation on coffee fields can affect the infiltration rate. The infiltration rate is the amount of water per unit time that enters the soil surface. The purpose of this study was to determine the infiltration rate with various shading, namely mixed shade (sengon, teak, pepper, and coconut), sengon shade, and monoculture coffee land and to determine the relationship between soil physical properties and infiltration rate on people's land. The measurement of the infiltration rate was done with a double ring infiltrometer and the Horton model. Infiltration rate can be influenced by a variety of soil properties such as bulk density, soil pore distribution, soil aggregate stability, soil texture, soil organic matter content, and land use. The analysis used correlation, linear regression, multiple linear regression, and t-test. Differences in shade and soil properties affect the infiltration rate, especially micropores and soil porosity. Soil with a lot of micro-pore soil, low porosity and clay texture has a slow infiltration rate. The results of the t-test between the actual infiltration rate and the infiltration rate of the Horton model showed no significant difference; therefore, the Horton method approach can be used in estimating the actual infiltration rate in coffee fields.
\end{abstract}

Keywords: double ring infiltrometer, Horton method, infiltration

\section{Pendahuluan}

Kopi merupakan salah satu hasil perkebunan yang memiliki nilai ekonomis cukup tinggi diantara tanaman perkebunan lainnya serta berperan penting sebagai sumber devisa negara. Salah satu hal yang mempengaruhi budidaya tanaman kopi adalah perubahan iklim seperti perubahan curah hujan yang tinggi sehingga mengakibatkan penurunan produksi dan terganggunya siklus hidrologi, maka perlu dilakukan tindakan penanaman vegetasi naungan. Siklus hidrologi dipengaruhi oleh proses aliran air yang masuk dalam tanah yang disebut infiltrasi. Infiltrasi adalah proses aliran air yang masuk ke dalam tanah dengan adanya gaya kapiler (Darmayanti, 2012). Air di permukaan tanah tidak semuanya mengalir ke dalam tanah tetapi sebagian air tetap tinggal di lapisan tanah bagian atas (top soil) yang akan menguap kembali ke atmosfer melalui permukaan tanah atau soil evaporation (Asdak, 2010).

Proses terjadinya laju infiltrasi dipengaruhi oleh beberapa faktor seperti tekstur dan struktur tanah, air tersedia, kandungan bahan organik, dan penutupan lahan dengan vegetasi atau sisasisa tanaman. Salah satu lokasi lahan tanaman kopi yang menggunakan tanaman naungan yaitu pada lahan tanaman kopi di Wilayah Sumbermanjing Wetan, Malang diantaranya lahan tanaman kopi dengan naungan campuran (sengon, lada, kelapa dan jati), lahan tanaman kopi dengan naungan sengon. Adapun lahan tanaman kopi yang tidak menggunakan vegetas sebagai naungan atau disebut monokultur. Pada perkebunan kopi rakyat, pohon penaung yang umum digunakan di antaranya adalah tanaman 
dadap, alpukat, petai, jengkol, sukun, lamtoro, dan sengon (Panggabean, 2011).

Tanaman penaung sebagai pelindung dapat mempengaruhi jumlah intensitas cahaya matahari yang diserap sehingga dapat meningkatkan kelembaban udara, mengurangi suhu udara ekstrim serta dapat meningkatkan laju infiltrasi suatu lahan. Perbedaan infiltrasi pada berbagai lahan menunjukkan bahwa faktor vegetasi yang digunakan untuk tanaman penaung memiliki peran besar dalam menentukan infiltrasi. Naungan yang ditanam pada lahan kopi dapat mempengaruhi jumlah air hujan yang terintersepsi di permukaan tanah dimana jumlah air yang masuk ke dalam tanah atau mencapai permukaan tanah secara langsung tergantung pada tanaman penutup yang digunakan (Pramono dan Adi, 2017).

Adanya berbagai tanaman penaung dengan vegetasi yang berbeda pada lahan kopi rakyat di wilayah Sumbermanjing Wetan sebagai bentuk mitigasi lingkungan, oleh karena itu perlu dilakukan penelitian mengenai laju infiltrasi pada berberapa lahan kopi dengan berbagai naungan di wilayah Sumbermanjing, Malang.

\section{Bahan dan Metode}

\section{Tempat dan waktu penelitian}

Penelitian laju infiltrasi pada berbagai naungan pada lahan kopi rakyat di wilayah Sumbermanjing Wetan dilaksanakan pada bulan Januari 2020 sampai Maret 2020. Lokasi penelitian untuk pengambilan contoh tanah dan pengukuran infiltrasi dilakukan di wilayah Sumbermanjing Wetan, Kabupaten Malang. Penelitian dilakukan dengan dua kegiatan yaitu kegiatan lapang dan analisis laboratorium. Pelaksanaan kegiatan analisis laboratorium dilakukan di Laboratorium Fisika tanah Universitas Brawijaya dan Laboratorium Kimia Badan Pengkajian Teknologi Pertanian (BPTP) Karangploso, Malang.

\section{Rancangan penelitian}

Penelitian ini dilaksanakan dengan menggunakan metode survei untuk menentukan naungan (dua naungan yang berbeda) dan satu lahan kopi tanpa naungan atau monokultur. Lahan kopi yang digunakan memiliki 3 plot pengamatan dan 9 titik pengamatan yang digunakan yaitu plot $\mathrm{C}$ terdiri dari tiga titik antara lain C1, C2, C3 (lahan kopi yang memiliki naungan campuran seperti sengon, lada, jati dan kelapa), plot $\mathrm{S}$ yang terdiri dari tiga titik antara lain S1,S2,S3 (lahan kopi dengan naungan sengon), dan plot $M$ yang terdiri dari tiga titik antara lain M1, M2, M3 (lahan kopi tanpa naungan atau monokultur).

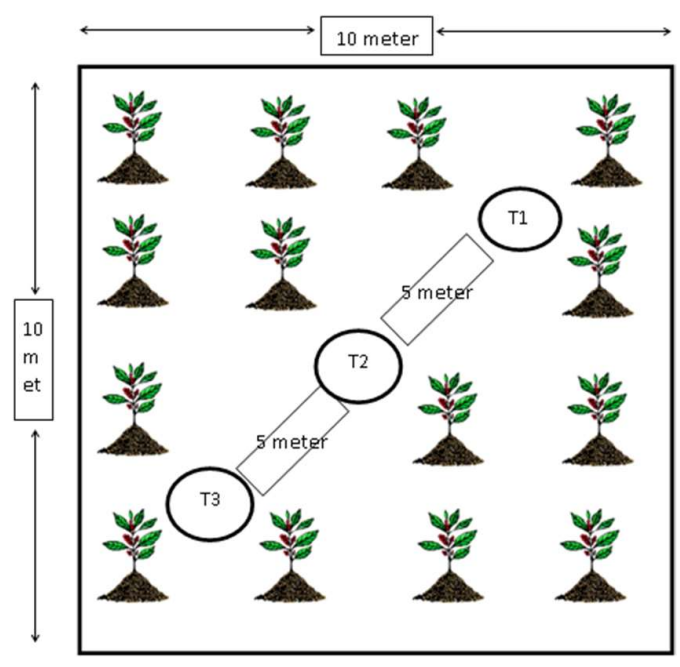

Gambar 1. Titik pengamatan.

\section{Metode}

\section{Pengukuran infiltrasi}

Pengukuran infiltrasi dilakukan menggunakan double ring infiltrometer di lahan kopi dengan berbagai naungan yang berbeda. Ring yang digunakan ada dua yaitu ring dalam dengan diameter $30 \mathrm{~cm}$ dan ring luar dengan diameter $50-60 \mathrm{~cm}$ serta panjang kedua ring yaitu 10-20 $\mathrm{cm}$.

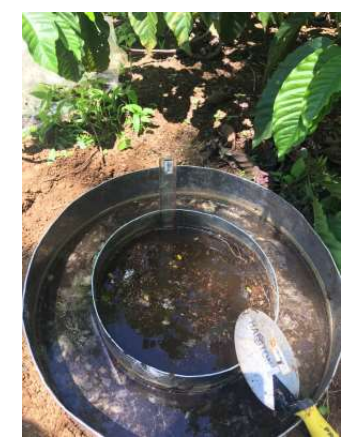

Gambar 2. Double Ring Infiltrometer. 


\section{Jurnal Tanah dan Sumberdaya Lahan Vol 8 No 1: 293-300, 2021 e-ISSN:2549-9793, doi: 10.21776/ub.jts1.2021.008.1.32}

Perhitungan laju infiltrasi dilakukan dengan perbandingan penurunan muka air saat konstan dengan waktu pengukuran.

$$
\mathrm{Ft}=\Delta \mathrm{h} / \Delta \mathrm{t}
$$

dimana :

$$
\begin{aligned}
\mathrm{ft} & =\text { laju infiltrasi }\left(\mathrm{cm} \mathrm{jam}^{-1}\right) \\
\Delta \mathrm{h} & =\text { penurunan muka air }(\mathrm{cm}) \\
\Delta \mathrm{t} & =\text { waktu (jam) }
\end{aligned}
$$

Hasil pengukuran nilai infiltrasi yang didapatkan, kemudian dilakukan perhitungan menggunakan model Horton dengan rumus sebagai berikut:

$$
F=f c+(f 0-f c) e^{-k t}
$$

\section{Dimana:}

$$
\begin{aligned}
\mathrm{f}= & \text { laju infiltrasi }\left(\mathrm{cm} \mathrm{jam}^{-1}\right) \\
\mathrm{f} 0= & \text { laju infiltrasi awal }\left(\mathrm{cm} \mathrm{jam}^{-1}\right) \\
\mathrm{fc}= & \text { laju infiltrasi konstan }\left(\mathrm{cm} \mathrm{jam}^{-1}\right) \\
\mathrm{e}= & 2,718 \\
\mathrm{t}= & \text { waktu dalam pengamatan (jam) } \\
\mathrm{k}= & \text { konstanta Horton yang mewakili } \\
& \text { penurunan daya tampung infiltrasi } \\
& \text { dengan rumus sebagai berikut: } \mathrm{k}= \\
& -1 /(0,4343 \mathrm{x} \mathrm{m}) ; \mathrm{m} \text { merupakan } \\
& \text { gradien dari plotting grafik } \\
& \text { hubungan antara waktu dan Log }(\mathrm{f}- \\
& \mathrm{fc}) .
\end{aligned}
$$

Sumber: Achmad (2011).

Penggunaan model Horton dilakukan karena Horton menyatakan bahwa pendugaan waktu pencapaian melalui turunan pertama didapatkan dari Model Horton sehingga dapat ditentukan waktu pencapaian laju infiltrasi (Agung, 2014).

\section{Parameter pengamatan lapang dan tanah}

Pengambilan sampel tanah utuh digunakan analisis berat isi, porositas dan ukuran pori tanah. Pengambilan sampel tanah agregat dilakukan untuk analisis tekstur, kandungan bahan organik, kemantapan agregat, dan ukuran pori tanah. Contoh tanah yang didapat kemudian dimasukkan ke dalam kantong plastik dan diberi label untuk keterangan. Perhitungan distribusi ukuran pori menggunakan metode pressure plate untuk pF 4,2 dan kaolin box untuk pF 1,dan 2. Berat isi menggunakan metode silinder, porositas ditetapkan menggunakan nilai berat isi dan berat jenis dengan rumus sebagai berikut:

Porositas $(\%)=(1-\mathrm{BI} / \mathrm{BJ})$ X $100 \%$.

Kemantapan agregat menggunakan metode ayakan basah yang membutuhkan tanah lolosan ayakan $8 \mathrm{~mm}$ sebanyak 20-50 gram, kemudian disusun dengan ayakan 4,$75 ; 2 ; 1$ ; 0,5; 0,25 mm Metode yang digunakan dalam penentuan tekstur tanah yaitu metode pipet.

\section{Analisis data}

Analisis data yang digunakan untuk mengetahui pengaruh parameter yang dilakukan dengan korelasi dan regresi menggunakan SPSS Statisticss 22 dan Microsoft Excel 2010. Untuk mengetahui hubungan antar parameter dilakukan uji korelasi pada taraf $5 \%$ dan $1 \%$ sehingga diketahui hubungan yang terjadi pada dua variabel (x dan y). Bamutaze et al. (2010) menggunakan analisis korelasi dan regresi untuk mengetahui hubungan karakteristik fisik tanah seperti tekstur, bahan organik, porositas, permeabilitas, kondisi tegakan pohon, dan kondisi penutupan tanah terhadap laju infiltrasi. Jika hasil korelasi menyatakan memiliki hubungan dan arah hubungan maka akan dilanjutkan dengan uji regresi, kemudian jika hasil menunjukkan $f$ hitung lebih besar dibandingkan $\mathrm{f}$ tabel maka akan dilanjutkan uji regresi berganda yang menghasilkan model persamaan. Langkah selanjutnya yaitu melakukan uji $\mathrm{T}$ untuk mengetahui apakah model Horton mampu digunakan dalam pendugaan laju infiltrasi di lahan kopi.

\section{Hasil dan Pembahasan}

\section{Kondisi umum wilayah}

Sumbermanjing Wetan berada di bagian selatan Kabupaten Malang. Luas wilayah Sumbermanjing Wetan seluas 118,51 $\mathrm{km}^{2}$ (sumber: Dinas PU Bina Marga Kabupaten Malang tahun 2018) dan sebagian besar wilayahnya berupa dataran tinggi perbukitan dengan ketinggian antara 0 hingga 650 meter diatas permukaan air laut. Sumbermanjing Wetan berada di koordinat antara $112^{\circ} 39^{\prime} 07^{\prime \prime}$ BT - $112^{\circ} 46^{\prime} 68^{\prime \prime}$ BT dan antara $8^{\circ} 13^{\prime} 68^{\prime \prime}$ LS $-8^{\circ} 28^{\prime} 02^{\prime \prime}$ LS. Pola penggunaan tanah pada 


\section{Jurnal Tanah dan Sumberdaya Lahan Vol 8 No 1: 293-300, 2021 e-ISSN:2549-9793, doi: 10.21776/ub.jts1.2021.008.1.32}

Sumbermanjing Wetan yaitu $2165 \mathrm{Ha}$ permukiman, $894 \mathrm{~km}^{2}$ Sawah, $7.802 \mathrm{~km}^{2}$ tegal/kebun, $3.250 \mathrm{~km}^{2}$ Perkebunan, $7.926 \mathrm{~km}^{2}$ Hutan, dan $180 \mathrm{~km}^{2}$ penggunaan tanah lainnya. Kecamatan Sumbermanjing Wetan memiliki kelerengan 15-40\% dan termasuk dalam kondisi daerah yang bergelombang (RPUM, 20112015). Rata-rata curah hujan Kecamatan Sumbermanjing Wetan selama satu tahun sekitar 33 milimeter (bulan September) dan 384 milimeter (bulan Februari) dimana saat musim kemarau sering terjadi kekurangan air atau kekeringan.

\section{Infiltrasi tanah}

Berdasarkan pengukuran laju infiltrasi aktual pada berbagai lahan kopi di wilayah Sumbermanjing Wetan, didapatkan hasil perbedaan laju nfiltrasi pada keseluruhan plot. Hal ini dapat terjadi karena setiap titik mengalami penurunan laju infiltrasi dengan bertambahnya waktu hingga didapatkan nilai laju infiltrasi konstan. Semakin cepat waktu yang dibutuhkan untuk infiltrasi konstan (44 menit), maka akan semakin tinggi laju infiltrasi (C2), sedangkan semakin lama waktu yang digunakan untuk mencapai infiltrasi konstan (66 menit) maka laju infiltrasi semakin rendah (M3). Hasil laju infiltrasi aktual tertinggi pada titik C2 sebesar 107,74 cm/jam memiliki arti bahwa dalam waktu 1 jam air mampu masuk ke dalam tanah sebesar $107 \mathrm{~cm}$ atau dalam waktu 1 jam kedalaman muka air mencapai $107 \mathrm{~cm}$ dalam tanah. Air yang meresap ke dalam tanah akan mengisi kekurangan kadar air tanah dimana tanah yang memiliki pori-pori berdiameter besar maka air akan mengalir ke tanah yang lebih dalam. Menurut Putra et al. (2013) bahwa waktu mempunyai pengaruh yang sangat besar terhadap laju infiltrasi tanah dimana semakin lama waktu untuk memasukkan atau meloloskan air ke dalam tanah maka akan semakin kecil laju infiltrasi yang terjadi. Waktu yang lama akan mengakibatkan tanah semakin jenuh sehingga sebagian rongga tanah akan terisi oleh tanahtanah yang halus sehingga ruang untuk pergerakan air akan berkurang. Laju infiltrasi rendah pada titik M3 dapat terjadi karena porositas tanah yang didominasi oleh pori mikro sebesar 14,18 \% dan persentase fraksi liat yang tinggi sebesar $58 \%$ sehingga laju infiltrasi pada lahan monokultur relatif rendah. Rendahnya laju infiltrasi pada hasil penelitian di titik M3 dapat dilakukan tindakan penyaluran air atau irigasi melalui pipa air yang dipendam dalam tanah untuk memberikan infiltrasi yang optimal pada lahan tanaman kopi monokultur.

Tabel 1. Hasil laju infiltrasi aktual seluruh plot.

\begin{tabular}{cccc}
\hline Lahan Kopi & $\begin{array}{c}\text { Laju Infiltrasi } \\
\left(\mathbf{c m ~ j a m}^{-1}\right)\end{array}$ & Klasifikasi & $\begin{array}{c}\text { Laju Infiltrasi Horton } \\
\mathbf{( c m ~ j a m}^{-1} \mathbf{)}\end{array}$ \\
\hline C1 & 75,52 & Agak Cepat & 66,71 \\
C2 & 107,74 & Agak Cepat & 98,64 \\
C3 & 40,44 & Sedang & 26,64 \\
S1 & 69,00 & Agak Cepat & 54,88 \\
S2 & 62,75 & Sedang & 39,20 \\
S3 & 42,41 & Sedang & 25,62 \\
M1 & 66,27 & Agak Cepat & 66,37 \\
M2 & 54,46 & Sedang & 46,23 \\
M3 & 26,74 & Sedang & 25,64 \\
\hline
\end{tabular}

\section{Kondisi sifat tanah terhadap laju infiltrasi}

Berat isi

Nilai berat isi yang tinggi dapat dipengaruhi oleh adanya pengolahan tanah yang dilakukan secara intensif. Hal ini dibuktikan dengan adanya pengolahan tanah dan dilakukan pemupukan pada saat sebelum dilakukan pengambilan sample tanah untuk analisis berat isi yang terjadi di lahan kopi naungan campuran dimana hasil nilai berat isi pada plot C titik C2 tinggi. Berdasarkan pendapat Wirosoedarmo et al. 


\section{Jurnal Tanah dan Sumberdaya Lahan Vol 8 No 1: 293-300, 2021 e-ISSN:2549-9793, doi: 10.21776/ub.jts1.2021.008.1.32}

(2009) bahwa pengolahan tanah dapat mempengaruhi nilai berat isi saat pengolahan tanah dilakukan secara intensif dapat menunjukkan kenaikan pada nilai berat isi. Pengolahan yang terlalu intensif sangat tidak dianjurkan karena akan menyumbat pori-pori tanah sehingga mengakibatkan tanah lebih padat dan berat isi meningkat (Arsyad, 2010). Vegetasi penutup yang rendah juga dapat mempengaruhi hasil dari nilai berat isi sesuai dengan pendapat Arifin (2010) yang mengatakan bahwa vegetasi dapat menahan daya pukulan butir-butir air hujan yang jatuh ke permukaan tanah sehingga mampu mengurangi kepadatan tanah.

Tabel 2. Nilai berat isi, porositas, kemantapan agregat, fraksi pasir, fraksi debu, fraksi liat, pori tanah, bahan organik.

\begin{tabular}{|c|c|c|c|c|c|c|c|c|c|}
\hline \multirow{2}{*}{$\begin{array}{l}\text { Parameter } \\
\text { Pendukung }\end{array}$} & \multicolumn{9}{|c|}{ Penggunaan Lahan } \\
\hline & C1 & $\mathrm{C} 2$ & $\mathrm{C3}$ & S1 & S2 & S3 & M1 & M2 & M3 \\
\hline Berat Isi $\left(\mathrm{g} \mathrm{cm}^{-3}\right)$ & 1,30 & 1,38 & 1,05 & 1,04 & 1,14 & 1,15 & 1,13 & 1,06 & 1,03 \\
\hline Porositas $(\%)$ & 50,96 & 44,88 & 55,56 & 56,27 & 49,90 & 52,50 & 54,19 & 55,18 & 53,92 \\
\hline $\begin{array}{l}\text { Kemantapan } \\
\text { Agregat }(\mathrm{mm})\end{array}$ & 1,98 & 0,99 & 4,23 & 2,27 & 2,30 & 3,07 & 2,95 & 4,02 & 2,71 \\
\hline Pasir (\%) & 19 & 18 & 12 & 20 & 21 & 20 & 21 & 19 & 15 \\
\hline Debu $(\%)$ & 32 & 47 & 35 & 37 & 38 & 40 & 36 & 34 & 27 \\
\hline $\operatorname{Liat}(\%)$ & 49 & 35 & 53 & 44 & 41 & 40 & 43 & 47 & 58 \\
\hline Makro (\%) & 13,11 & 13,17 & 10,01 & 19,47 & 19,13 & 15,04 & 11,36 & 16,46 & 6,05 \\
\hline Meso (\%) & 27,90 & 22,17 & 20,04 & 29,39 & 33,14 & 30,47 & 25,14 & 29,31 & 34,85 \\
\hline Mikro (\%) & 29,92 & 32,25 & 22,09 & 21,21 & 21,78 & 23,28 & 25,44 & 25,15 & 14,18 \\
\hline Bahan organik (\%) & 2,28 & 1,78 & 2,66 & 2,39 & 1,92 & 2,79 & 3,08 & 2,82 & 2,98 \\
\hline
\end{tabular}

Porositas

Persentase porositas tanah yang besar akan memliki tanah yang porous seperti pada titik S1 dimana pada hasil porositas tanah yang besar tetapi hasil nilai berat isi yang rendah. Pengolahan tanah secara insentif dapat menyebabkan struktur tanah kurang baik atau rusak sehingga dapat menurunkan porositas tanah dan menyebabkan kenaikan tingkat kepadatan tanah. Besarnya nilai porositas yang didapatkan terjadi karena adanya pengolahan tanah dalam waktu dekat akan membuat tanah yang diamati lebih remah, tetapi dalam waktu yang lama akan menyebabkan tanah padat. Hal tersebut akan mengakibatkan lebih mudah atau lebih cepat tanah dalam menyerap air dibandingkan tanah yang memiliki kategori tanah mampat. Tanah mampat akan memiliki pori tanah yang lebih padat dibandingkan dengan tanah yang porous. Tanah yang memiliki pori berukuran besar, umumnya dapat mempunyai kemampuan yang menyimpan kelembaban tanah yang rendah tetapi besar dalam proses melewatkan air dan udara dalam tanah (Arifin,2011).

\section{Kemantapan agregat}

Perbedaan kemantapan agregat yang terjadi pada keseluruhan lahan kopi dapat terjadi karena beberapa pengaruh seperti vegetasi penutup yang terdapat pada lahan kopi, tekstur tanah, dan kandungan bahan organik. Hal ini sesuai dengan pendapat Refliaty et al. (2010) bahwa stabilitas agregat tanah salah satunya dapat dipengaruhi oleh vegetasi yang tumbuh di atasnya dimana vegetasi dapat melindungi tanah dari pukulan butir air hujan serta mengurangi energi kinetik melalui tajuk, ranting dan batang. Tekstur tanah dikatakan dapat mempengaruhi kemantapan agregat karena fraksi liat adalah zat yang mampu merekatkan partikel tanah sehingga terbentuk fraksi yang sangat stabil sekali atau mantap. Tanaman mampu mempengaruhi kemantapan agregat suatu tanah karena perakaran tanaman yang menembus tanah sehingga membentuk celah pada tanah sehingga terjadi daya tekanan dari akar yang menyebabkan tanah akan semakin padat. Faktor eksternal yang dapat mempengaruhi kemantapan agregat tanah diantaranya 


\section{Jurnal Tanah dan Sumberdaya Lahan Vol 8 No 1: 293-300, 2021 e-ISSN:2549-9793, doi: 10.21776/ub.jts1.2021.008.1.32}

pengolahan tanah yang dilakukan pada lahan kopi dengan secara intensif.

\section{Tekstur tanah}

Tekstur tanah yaitu perbandingan kandungan partikel tanah seperti fraksi pasir, debu, dan liat yang terdapat pada suatu masa tanah (Yuliprayanto, 2010). Hasil yang didapatkan oleh tanah yang bertekstur liat yaitu persentase kandungan liatnya lebih besar dibandingkan dengan kandungan fraksi lain. Hal ini sesuai dengan pendapat Kartasapoetra dan Sutedjo (2010) bahwa tekstur tanah dibagi menjadi tiga golongan dasar seperti, 1. Tekstur berpasir dengan kandungan pasir sekitar 75\% hingga $85 \%, 2$. Tekstur berlempung dengan kandungan debu dan liat yang relatif sama, dan 3. Tekstur liat yang memiliki kandungan liat $>35 \%$, tetapi perbandingan ketiga fraksinya hampir seimbang. Berdasarkan persentase fraksi yang didapatkan dimana volume pori tanah lebih kecil karena persentase fraksi liat lebih tinggi sehingga proses laju infiltrasi relatif lambat dibandingkan jika persentase fraksi pasir lebih besar maka volume pori tanah akan lebih besar atau memiliki tekstur tanah yang kasar sehingga laju infiltrasi akan lebih cepat.

Pori tanah

Pori tanah makro pada keseluruhan titik S1 dan S2 memiliki pori yang tinggi, tetapi pada titik M3 memiliki pori yang rendah, dan keenam titik lainnya memiliki pori yang sedang. Pori tanah meso dikatakan tinggi jika memiliki persentase lebih dari $15 \%$ sehingga pada keseluruhan titik termasuk dalam kategori tinggi (Lembaga Penelitian Tanah, 1980). Titik M3 yang dilakukan pengamatan memiliki pori mikro yang termasuk dalam pori yang sedang, sedangkan kedelapan titik lainnya memiliki pori yang tinggi. Tanah yang didominasi oleh pori tanah berukuran besar (pori makro), pada umumnya mampu melakukan proses peresapan air dan udara yang tinggi dan kemampuan menyimpan lengas yang rendah (Arifin, 2010). Pori meso yang tinggi seperti pada titik M3 menunjukkan bahwa tanah mampu mempertahanakan kelembaban yang lebih lama dibandingkan dengan titik lain yang memiliki pori meso yang lebih rendah. Pori makro yang tinggi pada titik S1 menunjukkan bahwa air akan terus masuk ke dalam tanah dengan kecepatan yang lebih tinggi dibandingkan dengan titik lainnya.

\section{Bahan organik}

Naungan berpengaruh terhadap bahan organik tanah dimana lahan yang memliki naungan akan memiliki banyak sumber utama bahan organik seperti daun, ranting, batang, dan sisa tanaman sehingga akan mempengaruhi struktur tanah serta tanah menjadi remah. Hal ini menyebabkan bahan organik tinggi sehingga berat isi rendah dan porositas tanah tinggi, maka laju infiltrasi akan relatif tinggi. Peningkatan jumlah bahan organik tanah merubah struktur tanah yang dapat meningkatkan porositas tanah (Schiavon et al., 2020). Titik M1 didapatkan daun dan ranting lebih banyak dibandingkan dengan titik lainnya karena memiliki kerapatan tajuk yang lebih rapat dan daun yang lebih lebat. Aktivitas pengolahan tanah dan penambahan pupuk juga dapat memicu tingginya kandungan bahan organik tanah. Hal ini didukung dengan pernyataan Darmayanti (2012) bahwa aktivitas pengolahan tanah dan penambahan pupuk organik akan memicu aktivitas mikroorganisme untuk melakukan penguraian bahan organik tanah sehingga meningkatkan bahan organik pada tanah. Rendahnya kandungan bahan organik tanah dapat terjadi karena vegetasi yang menyumbangkan bahan organik lebih sedikit seperti pada lahan kopi campuran yang memiliki daun lebih sedikit saat dilakukan penelitian pada titik pengamatan keadaan tanaman kopi lebih memiliki sedikit vegetasi yang jatuh ke permukaan.

\section{Keterkaitan karakteristik tanah terhadap laju infiltrasi}

Korelasi parameter tanah dengan laju infiltrasi

Hasil analisis korelasi didapatkan adanya arah hubungan positif dan negatif (-). Arah hubungan positif atau berbanding lurus memiliki arti bahwa semakin tinggi nilai suatu variabel bebas maka semakin tinggi laju infiltrasi sebagai variabel terikat, sedangkan arah hubungan negatif atau berbanding berlawanan memiliki arti bahwa semakn tinggi variabel bebas (parameter) maka samkin rendah laju infiltrasi (variabel terikat). Berdasarkan hasil keseluruhan parameter yang dilakukan analisis korelasi, kemudian akan dilakukan analisis regresi linier 


\section{Jurnal Tanah dan Sumberdaya Lahan Vol 8 No 1: 293-300, 2021 e-ISSN:2549-9793, doi: 10.21776/ub.jts1.2021.008.1.32}

untuk parameter yang memiliki nilai signifikansi $<0,05$ diantaranya berat isi, porositas, kemantapan agregat, pori mikro, bahan organik, fraksi debu dan fraksi liat.

\section{Uji regresi linier}

Parameter yang dilakukan analisis regresi linier yaitu berat isi, porositas, kemantapan agregat, pori mikro, bahan organik, fraksi debu dan fraksi liat. Keseluruhan parameter yang dilakukan uji linier berpengaruh nyata terhadap laju infiltrasi dengan memperhatikan nilai signifikansi parameter $<0,05$.

Regresi linier berganda

Hasil regresi linier berganda laju infiltrasi aktual didapatkan hasil persamaan regresi sebagai berikut :

$\mathrm{Y}=-72,60+63,35 \mathrm{X} 1+2,54 \mathrm{X} 2$

Dimana: $\mathrm{Y}=$ Infiltrasi Aktual $\left(\mathrm{cm} \mathrm{jam}^{-1}\right), \mathrm{X} 1=$ Berat Isi $\left(\mathrm{g} \mathrm{cm}^{-3}\right), \mathrm{X} 2=$ Pori Mikro (\%).

Hasil regresi linier model Horton sebagai beirkut:

$\mathrm{Y}=156,63+5,30 \mathrm{X} 1-157,31 \mathrm{X} 2-19,76 \mathrm{X} 3$

dimana: $\mathrm{Y}=$ Infiltrasi model Horton $\left(\mathrm{cm} \mathrm{jam}^{-1}\right)$, $\mathrm{X} 1=$ Pori Mikro (\%), X2= Berat Isi $\left(\mathrm{g} \mathrm{cm}^{-3}\right)$, X3 = Kemantapan Agregat (mm).

$U j \ddot{i}-t$

Hasil uji regresi berganda antara laju infiltrasi aktual dan laju infiltrasi model horton selanjutnya dilakukan uji-t untuk mengetahui ada tidaknya perbedaan yang nyata. Hasil uji-t didapatkan bahwa H0 diterima yang artinya antara data pengukuran laju infiltrasi aktual dengan laju infiltrasi metode Horton tidak terdapat perbedaan yang nyata. Berdasarkan hasil analisis statistik dapat disimpulkan bahwa metode Horton dapat digunakan untuk memperkirakan laju infiltrasi aktual di lahan kopi.

\section{Pembahasan umum}

Nilai laju infiltrasi yang terjadi pada keseluruhan lahan kopi memiliki nilai yang beragam yang dapat terjadi karena ada perbedaan vegetasi yang ada di lahan kopi. Hal ini sesuai dengan pernyataan Agustina (2012), bahwa nilai infiltrasi dapat berbeda-beda pada suatu tempat yang berbeda dan waktu yang berbeda pula yang ditentukan oleh tipe penggunaan lahan. Tingginya nilai berat isi tanah pada titik C2, dan rendahnya berat si tanah pada titik M3 dapat terjadi dipengaruhi oleh vegetasi tutupan lahan (naungan) yang ada pada lahan kopi di wilayah Sumbermanjing Wetan. Tanah yang memiliki banyak pori tertentu akan mengakibatkan rendahnya berat isi tanah, sebaliknya jika tanah memiliki pori tertentu dalam jumlah rendah maka tanah akan memiliki berat isi yang tinggi (Sartohadi et al., 2012).

Pengaruh kandungan bahan organik dan pengolahan tanah hanya bersifat sementara dalam proses penggemburan tanah yang selanjutnya akan berubah sesuai dengan kondisi lingkungan (Arsyad, 2010). Hasil yang didapatkan bahwa tekstur pada titik C2 adalah lempung liat berdebu, S3 Liat Berdebu, dan titik lainnya memliki tekstur Liat. Hasil persentase fraksi debu dan liat lebih besar dibandingkan dengan fraksi pasir. Tanah berlempung seperti titik C2 merupakan tanah yang sifatnya berada diantara tanah berpasir dan berliat sehingga tata udaranya cukup baik untuk menyimpan, menyediakan air untuk tanaman (Arifin, 2010). Hal ini dapat menyebabkan air lebih mudah diserap oleh tanah karena tanah bertekstur lempung liat berdebu termasuk dalam tekstur sedang yang agak halus sehingga tanah lebih mudah meloloskan air dibandingkan dengan tanah yang bertekstur liat. Tingginya nilai agregat tanah atau semakin stabil akan mempertahankan sifat-sifat tanah yang baik seperti porositas dan ketersediaan air lebih lama jika dibandingkan dengan tanah yang memiliki agregat tanah yang tidak mantap atau tidak stabil. Tanah yang memiliki agregat mantap akan mampu mempertahankan kondisi tanah dari adanya hujan dan pengolahan tanah (Yulnafatmawati et al,. 2012).

Kandungan bahan organik yang meningkat maka aktivitas mikroorganisme tanah akan tinggi sehingga mampu memperbaiki porositas dan stabilitas agregat tanah sehingga dapat membantu cepatnya air masuk ke dalam tanah (Cardoso et al., 2013). Pendapat tersebut berlawanan dengan hasil yang didapatkan pada beberapa titik seperti titik C2, C3, dan M3 dimana semakin tinggi nilai bahan organik maka laju infiltrasi mengalami penurunan, sebaliknya saat nilai bahan organik rendah maka laju infiltrasi semakin tinggi. 


\section{Jurnal Tanah dan Sumberdaya Lahan Vol 8 No 1: 293-300, 2021 e-ISSN:2549-9793, doi: 10.21776/ub.jts1.2021.008.1.32}

\section{Kesimpulan}

Laju infiltrasi aktual di lahan kopi dan naungan yang berbeda memiliki hasil yang beragam dimana lahan tanaman kopi dengan naungan campuran memiliki laju infiltrasi aktual yang lebih besar yaitu sebesar $107,74 \mathrm{~cm} \mathrm{jam}^{-1}$. Sifat fisik dan kimia tanah berpengaruh nyata terhadap laju infiltrasi tanah aktual dan terhadap laju infiltrasi model horton. Hasil uji-t didapatkan bahwa $\mathrm{HO}$ diterima yang artinya antara data pengukuran laju infiltrasi aktual dengan laju infiltrasi metode Horton tidak terdapat perbedaan yang nyata. Berdasarkan hasil tersebut dapat disimpulkan bahwa metode Horton dapat digunakan untuk memperkirakan laju infiltrasi aktual di lahan kopi.

\section{Daftar Pustaka}

Achmad, M. 2011. Buku Ajar Hidrologi Teknik.Hibah Penulisan Buku Ajar bagi Tenaga Akademik: Keteknikan Pertanian Fakultas Teknologi Pertanian Universitas Hasanuddin.

Agung, C.W. 2014. Pengaruh Kelembaban Tanah Terhadap Waktu Pencapaian Kapasitas Infiltrasi di Berbagai Penggunaan Lahan. Skripsi. Fakultas Pertanian, Institut Pertanian Bogor. Bogor. 64 p.

Agustina, D., Setyowati, D.L. dan Sugiyanto. 2012. Analisis Kapasitas Infiltrasi pada Beberapa Penggunaan Lahan di Kelurahan Sekaran Kecamatan Gunungpati Kota Semarang. Jurnal Geo-Image 1(1) : 92-96.

Arifin, M. 2010. Kajian sifat fisik tanah dan berbagai penggunaan lahan dalam hubungannya dengan pendugaan erosi tanah. Jurnal Pertanian MAPETA 12(2):72-144.

Arifin, Z. 2011. Analisis nilai indeks kualitas tanah Entisol pada penggunaan lahan yang berbeda. Jurnal Agroteksos 21(1) : 47-54.

Arsyad, S. 2010. Konservasi Tanah dan Air. IPB Press. Bogor.

Asdak, C. 2010. Hidrologi dan Pengelolaan Daerah Aliran Sungai. Buku. Gadjah Mada University Press. Yogyakarta. 630 p.

Bamutaze, Y., Tenywa, M.M., Majaliwa, M.J.G., Vanacker, V., Bagoora, F., Magunda, M., Obando, J. and Wasige, J.E. 2010. Infiltration characteristics of volcanic sloping soils on $\mathrm{Mt}$. Elgon, Eastern Uganda. Catena 80(2010) 122130.

Cardoso, E.J.B.N., Vasconcellos, R.L.F., Bini, D., Miyauchi, M.Y.H., dos Santos, C.A., Alves, P.R. L., de Paula, A.M., Nakatani, A.S., Pereira, M. and Nogueira, M.A. 2013. Soil health: looking for suitable indicator. what should be considered to assess the effects of use adn management on soil health?. Scientia Agricola 70: 274-298

Darmayanti, A.S. 2012. Beberapa sifat fisika kimia tanah yang berpengaruh terhadap model kecepatan infiltrasi pada tegakan mahoni. Berkala Penelitian Hayati 17: 185-191.

Kartasapoetra, A.G. dan Sutedjo, M.M. 2010. Teknologi Konservasi Tanah dan Air. (Jakarta: Rineka Cipta).

Lembaga Penelitian Tanah. 1980. Sistem Klasifikasi Tanah. Dalam TOR Tipe-B Pemetaan Tanah dan Lingkungan. Proyek Penelitian Pertanian Menunjang Transmigrasi (P3MT). Bogor. Publ. No. E-2/80

Panggabean, E. 2011. Buku Pintar Kopi. PT Agro Media Pustaka. Jakarta Selatan. p. 124-132

Pramono, I.B. dan Adi R.H. 2017. Pendugaan infiltrasi menggunakan data neraca air di Sub Daerah Aliran Sungai Watujali, Gombong. Jurnal Penelitian Pengolahan Daerah Aliran Sungai 1(1): 35-48.

Putra, E., Sumono, Ichwan, N. dan E. SusE. 2013. Kajian laju infiltrasi tanah pada berbagai penggunaan lahan di Desa Tongkoh Kecamatan Dolat Rayat Kabupaten Karo. Jurnal Rekayasa Pangan dan Pertanian 1(2): 41 - 43.

Refliaty, dan Marpaung E.J. 2010. Kemantapan agregat ultisol pada beberapa penggunaan lahan dan kemiringan lereng. Jurnal Hidrolitan 1(2): $35-$ 42.

Sartohadi, J. 2012. Pengantar Geografi Tanah. Pustaka Pelajar, Yogyakarta.

Schiavon, V., Maria, I.C., Rosa, O., Rocha, G.C., Simas, F., Moura, W., Santana, F.C., Veloso, G.V. and Luz, J.M. 2020. The establishment of a secondary forest in a degraded pasture to improve hydraulic properties of the soil. Soil \& Tillage Research, $104538 . \quad$ doi: 10.1016/j.still.2019.104538.

Wirosoedarmo, R., Suharto, B. dan Hijriyati, W.R. 2009. Evaluasi laju infiltrasi pada beberapa penggunaan lahan menggunakan metode infiltrasi horton di Sub DAS Coban Rondo Kecamatan Pujon Kabupaten Malang. Jurnal Teknologi Pertanian 10(2): 88-96.

Yulipriyanto, H. 2010. Biologi Tanah dan Strategi Pengelolaannya. Graha Ilmu. Yogyakarta.

Yulnafatmawita, A., Naldo, R.A. dan Rasyidin, A. 2012. Analisis sifat fisika ultisol tiga tahun setelah pemberian bahan organik segar di daerah tropis basah Sambar. Jurnal Solum 9 (2): 91-97. 